\title{
A Comparison of the Utilization of Carbon Nanopowder and Activated Carbon as Counter Electrode for Monolithic Dye-Sensitized Solar Cells (DSSC)
}

\author{
Zaky Mubarak ${ }^{\text {a }}$, Natalita Maulani Nursam ${ }^{\text {b, * , Shobih }}{ }^{\text {, }}$, Jojo Hidayat ${ }^{\text {b }}$ \\ Dahlang Tahir ${ }^{a}$ \\ ${ }^{a}$ Department of Physics \\ Hasanuddin University \\ Jl. Perintis Kemerdekaan KM. 10 \\ Makassar, Indonesia \\ ${ }^{b}$ Research Center for Electronics and Telecommunication \\ Indonesian Institute of Sciences (P2ET-LIPI) \\ Komplek LIPI Gedung 20 lantai 4, Jl Sangkuriang Cisitu \\ Bandung, Indonesia
}

\begin{abstract}
Monolithic design is one of the most promising dye-sensitized solar cell (DSSC) architectures to develop, because it allows the elimination of one conductive substrate and offers the possibility for printing layer-by-layer of the materials that made up its structure. In this study, titanium dioxide-based monolithic type DSSCs were fabricated on a single fluorinedoped transparent oxide coated glass with $\mathrm{TiO}_{2}$ as photoanode and porous $\mathrm{ZrO}_{2}$ as spacer. The type of the carbon material used as the composite paste for the counter electrode was varied to see the effect on the solar cell efficiency. Four-point probes measurement revealed that the resistivity of the carbon layer synthesized using activated carbon exhibited slightly higher conductivity with a sheet resistance of $10.70 \Omega / \mathrm{sq}$ and $11.09 \Omega / \mathrm{sq}$ for activated carbon and carbon nanopowder, respectively. The efficiency of DSSC that uses activated carbon as counter electrode was higher (i.e. $0.221 \%$ ) than the DSSC with carbon nanopowder (i.e. $0.005 \%$ ). The better performance of DSSC with activated carbon as a counter electrode was due to its better conductivity and higher surface area compared to those of carbon nanopowder.
\end{abstract}

Keywords: carbon paste, counter electrode, dye-sensitized solar cells (DSSC).

\section{INTRODUCTION}

The energy issue is a major problem faced by almost all countries in the world. This phenomenon occurs mainly due to the rapid growth of world economy so that human needs for energy source has increased. The source of energy around the world itself is still dominated by fossil fuel-based energy sources, such as petroleum, natural gas and coal. Because of the limited energy derived from fossil materials, it is thus necessary to develop as well as to research new-and renewable energy sources. Therefore, the discovery of renewable alternative energy sources is essential for the continuity and the sustainability of the energy supply. One of the possible solutions to these energy challenges is the utilization of abundant, continuous, clean and efficient renewable energy sources [1]. Sun is a potential source of energy for human needs. The supply of solar energy from sunlight received by the earth's surface reaches $3 \times 10^{24}$ joules per year [2]. The amount of solar energy equals to 10.000 times the annual energy consumption worldwide or equivalent to $2 \times 10^{17} \mathrm{~W}$ [2]. In another word, covering only 0.1 percent of the Earth's surface with solar cell device that has a 10 percent

\footnotetext{
* Corresponding Author.

Email: natalita.maulani.nursam@lipi.go.id

Received: March, 062018 ; Revised: April, 232018

Accepted: May, 092018 ; Published: August, 312018

(C) 2018 PPET - LIPI
}

efficiency is capable of covering the energy needs of today's world [2].

The solar cell technology that dominates the worldwide market at the moment is silicon-based solar cells with an efficiency of approximately $15-20 \%$. However, silicon-based solar cells still have many weaknesses that cause relatively high selling price. One of the weaknesses lies on the production processes that require very complex fabrication steps (i.e. purification, crystallization process, and fabrication). To solve this problem, researchers then developed a new type of solar cell that is cheap, simple in its production process and environmentally friendly. This type of solar cell is socalled dye-sensitized solar cell (DSSC) [3].

DSSC, or also called Gratzel cell, was first discovered by Michael Gratzel and Brian O'Regan in 1991 at the Ecole Polytechnique Federale de Lausanne, Switzerland. Unlike conventional solar cells, DSSC is a photoelectrochemical solar cell that uses electrolytes as a medium of charge transport to convert sunlight into electrical energy. Its conversion efficiency has currently reached $10-15 \%$ [4]. DSSC technology mimics the ability of plants converting sunlight into energy in the photosynthesis process. In DSSC, chlorophyll is replaced by a light-absorbing color, in which the molecule is excited to a higher energy form by the incoming light. This energy is collected by the structure 
of electrolytes and catalysts, which is more like a leaf in photosynthesis [5].

In addition to the semiconductors in the photoanode and electrolyte that maintain their voltage in the DSSC cycle, counter electrode is an important factor in the continuous cycle of current and voltage production. The main function of the counter electrode is as a catalyst for accelerating the reduction of iodine/triiodide to the electrolyte, thus speed up the DSSC to produce electricity [6]. One of the materials often used as a catalyst in DSSC is platinum. However, due to its expensive price, it is preferably replaced by an easily available and cheaper materials. There have been numerous studies attempting to replace the role of platinum with carbon materials such as carbon black, activated carbon, single or multi-wall carbon nanotubes, graphene oxide, or reduced graphene oxide [6].

In this research, carbon paste was used as a counter electrode in DSSC. The type of the carbon material was varied in order to see the effect on the efficiency of monolithic structured solar cells. There are several advantages of the carbon material utilization as counter electrode, for instance, it is affordable and easier to provide than other catalyst materials such as platinum. In addition, carbon also has corrosion-resistant properties and has good electro-catalytic ability [6]. Furthermore, our previous result showed that carbon produced better performance than sputtered platinum when applied as the counter electrode in monolithic DSSC [7]. In particular, carbon nanopowder and activated carbon will be compared. The purpose of this study is to determine which carbon type will be more superior to be used as a counter electrode for monolithic DSSC. The results of this study are expected to support the development of monolithic DSSC in the future.

\section{METHODOLOGY}

\section{A. Materials}

Materials used in this research are Fluorine-doped transparent oxide $\left(\mathrm{SnO}_{2}: \mathrm{F}\right)$ coated glasses or FTO with a conductivity of $\sim 15 \Omega / \mathrm{sq}$ (Dyesol, TEC15), $\mathrm{TiO}_{2}$ opaque paste (Dyesol, 18NR-AO), ruthenium based dye (Z907), ionic liquid electrolyte (Dyesol, EL-HPE), stencil remover paste (No. 5, Ulano Corp, USA), degreaser (No. 23, Ulano Corp.), photographic film (Line, Ulano Corp.), sensitizer (No. 133, Ulano Corp.) and low temperature thermoplastic sealant (DuPont Surlyn ${ }^{\circledR}$ ) were purchased from Dyesol ${ }^{\mathrm{TM}}$ (recently renamed as Greatcell Solar), Australia. Meanwhile, the $\mathrm{ZrO}_{2}$ paste (Zr-Nanoxide ZR/SP, 20-40 nm, 30 wt\%) and carbon nanopowder (amorphous, $<50 \mathrm{~nm}, \geq 99 \%$ trace metals basis) were supplied by Solaronix, Switzerland and Aldrich, respectively. The other materials used were activated carbon (Arang Obat Ajaib ${ }^{\mathrm{TM}}$ ), ethyl-cellulose (Merck), $\mathrm{TiO}_{2}$ powder (P25, Degussa, Germany) and $\alpha$-terpineol (Aldrich). Colloidal graphite was purchased from Polaron Instruments Inc. Isopropyl alcohol and ethanol (both reagent grade) were obtained from Merck. Millipore water with resistivity higher than $15 \mathrm{M} \Omega$ was used throughout the experiments.

\section{B. Cell Fabrication}

The fabrication was started by making the structural design of monolithic DSSC using CorelDraw X7 as shown in Figure 1. The design was then printed on a transparent plastic sheet.

Next step was the process of making the design on the screen mesh. The designated screen mesh was made of stainless steel for carbon layer, while nylon-based screen mesh was used for printing $\mathrm{ZrO}_{2}$ and $\mathrm{TiO}_{2}$ layer. First, the screen mesh was cleaned from dirt and oil using stencil remover paste (No. 5, Ulano Corp, USA) and fabric abrader \& degreaser (No. 23, Ulano Corp.), and then dried. The screen mesh was then attached with photographic film (Line, Ulano Corp.) on one side, while a mixture of screen emulsion and sensitizer (No. 133, Ulano Corp.) was coated on the opposite side. Later, the design on a transparent plastic sheet was transferred onto the photographic film and the screen mesh was then exposed under UV beam on a screen maker (3000 TT, Richmond Graphic Products, Inc, USA) for $5 \mathrm{~min}$. The plastic sheet was then removed from the screen mesh and the screen was subsequently cleaned with water until the desired pattern appeared on the screen.

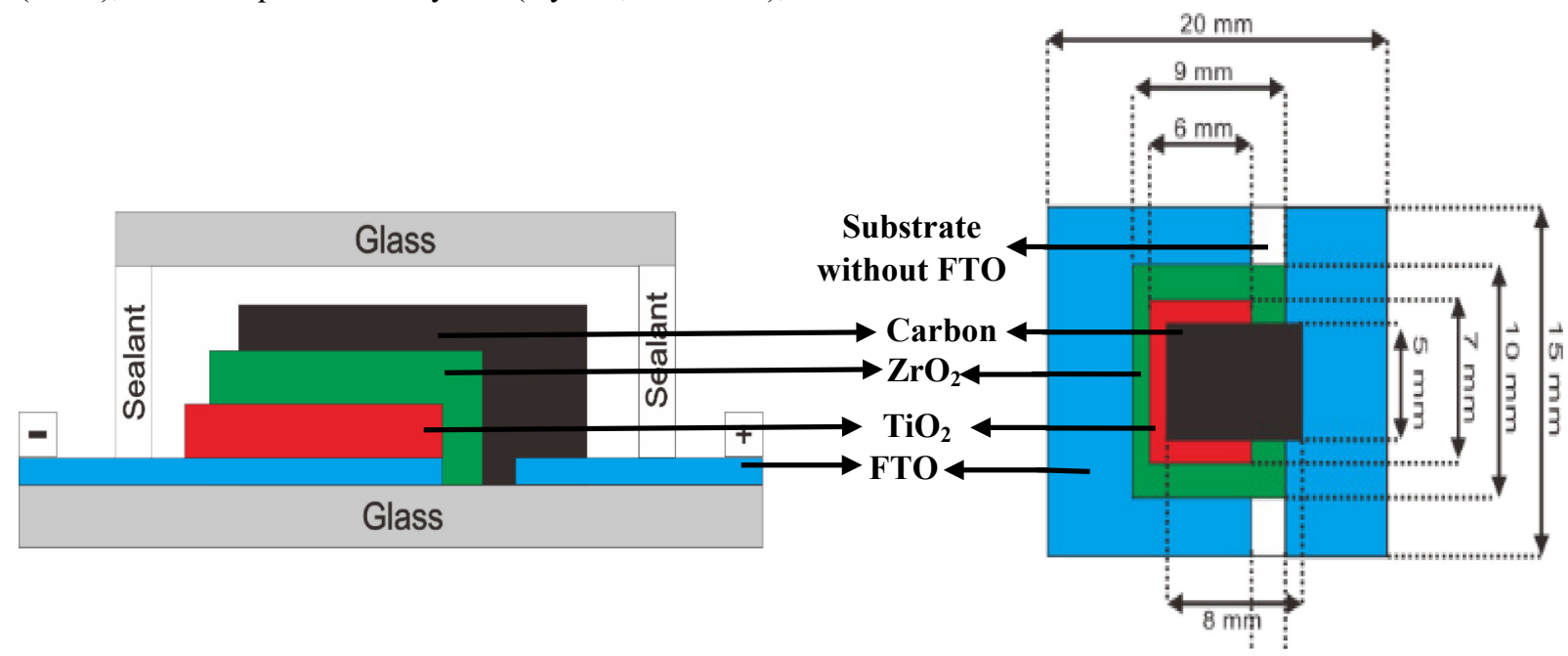

(a)

(b)

Figure 1. Geometrical structure design of monolithic DSSC a) from side view, and b) from top view. 
FTO substrate glass (TEC15, Dyesol Industries Pty, Ltd, Australia) cut to $20 \mathrm{~mm} \times 15 \mathrm{~mm}$ sizes and sanded on areas where the FTO layer was removed. The sanded FTO substrate glass was washed in acetone (Merck, Germany), soapy water, DI water, and isopropyl alcohol (PT. Brataco, Indonesia) for $10 \mathrm{~min}$ each using ultrasonic cleaner bath (Branson 3200, Emerson Electric Co, USA). Carbon paste was made by grounding carbon nanopowder (Aldrich, Germany)/activated carbon, graphite powder, ethyl-cellulose (Merck), $\mathrm{TiO}_{2}$ powder (P25, Degussa, Germany) and $\alpha$-terpineol (Aldrich). First, each material was weighed according to its dose. There were two variations of carbon paste made in this work, which is listed in Table 1. Each powder was crushed until smooth for approximately $2 \mathrm{~h}$ using a mortar and pestle. After the mixture of the carbon paste had already smooth, it was then stored in a small bottle.

The layers on monolithic DSSC were deposited by screen printing method. $\mathrm{TiO}_{2}$ paste was printed twice on the FTO substrate glass and dried at $120{ }^{\circ} \mathrm{C}$ for $10 \mathrm{~min}$ after each deposition before sintered at $500{ }^{\circ} \mathrm{C}$ in conveyor furnaces (Lindberg, USA) for $40 \mathrm{~min}$. The sintered films were then immersed in $40 \mathrm{mM}$ of $\mathrm{TiCl}_{4}$ aqueous solution to $70{ }^{\circ} \mathrm{C}$ for $30 \mathrm{~min}$ as a posttreatment, followed by another annealing under the same conditions as the $\mathrm{TiO}_{2}$ sintering. The function of $\mathrm{TiCl}_{4}$ treatment is to obtain a layer of $\mathrm{TiO}_{2}$ reflector aiming at capturing more light (e.i. light harvesting) [8]. When the substrate was cool, Zr-Nanoxide paste was printed twice on top of $\mathrm{TiO}_{2}$ layer and dried at $120{ }^{\circ} \mathrm{C}$ for $10 \mathrm{~min}$ after each deposition before sintered at 400 ${ }^{\circ} \mathrm{C}$ for $40 \mathrm{~min}$ in a conveyor furnace. Carbon paste was subsequently printed on top of the $\mathrm{ZrO}_{2}$ layer and dried in conveyor oven (Radiant Technology Corp, USA) at $120{ }^{\circ} \mathrm{C}$ for $30 \mathrm{mins}$ and sintered at $400{ }^{\circ} \mathrm{C}$ for $40 \mathrm{~min}$. The samples were then soaked in dye solution (Z907 Ru-dye, Solaronix $0.25 \mathrm{mM}$ in ethanol) for $20 \mathrm{~h}$ in the dark place. The dyed samples were then assembled with glass using thermoplastic and pressed for $120{ }^{\circ} \mathrm{C}$ for 30 s. Electrolyte (EL-HPE, Dyesol) was dropped in the gap between the glass substrates before sealed with sealing paste (Hermetic Sealing Compound A \& B, Dyesol) and then dried.

\section{Characterizations}

The characterization of this monolithic DSSC solar cell includes measurement of carbon paste thickness, sheet resistance measurement, scanning electron microscopy (SEM), surface area measurement, X-ray diffraction (XRD) analysis, and electrical properties characterizations. Measurement of carbon thickness was performed using thickness gauge. The morphology and microstructure of the carbon paste were observed by SEM. The surface area of the carbon pastes was observed using nitrogen gas sorption technique (Quantachrome) and calculated using BrunauerEmmett-Teller (BET) theory using Quantachrome NovaWin software. The carbon paste samples were dried and collected as powders, and then degassed at $150{ }^{\circ} \mathrm{C}$ prior to the gas sorption measurement. The sheet resistance of the carbon paste was measured using fourpoint probe (Alessi) with Hewlett-Packard 3468A multimeter and 6186C DC current source. The XRD measurement was conducted on Rigaku, RINT diffractometer with $\mathrm{Cu} \mathrm{K \alpha}$ radiation $(\lambda=1.54056 \AA)$. The photovoltaic properties of the cells were analyzed by measuring the current-voltage characteristics using National Instrument I-V measurement system under simulated solar irradiation with AM1.5G filter and an intensity of $50 \mathrm{~mW} / \mathrm{cm}^{2}$. The measurements were conducted at room temperature under dark and illuminated condition. The active area of each cell was $0.25 \mathrm{~cm}^{2}$

\section{RESULTS AND DISCUSSIONS}

The synthesis of carbon paste was carried out using two variations of carbon material, i.e, carbon nanopowder and activated carbon ( 5 samples for each variation). Table 2 shows that the carbon pastes using activated carbon (AC) have a smaller average thickness than the carbon pastes using carbon nanopowder (CNP).

The thickness of the carbon layer as the optimum counter electrode in the range 60-70 $\mu \mathrm{m}$ (to obtain low resistance) [9]. The thickness of the resulting carbon paste herein is thinner than the optimum thickness. Therefore, optimization of the printing process in the future is required in order to increase the thickness of the carbon layer following the optimum thickness reported in the literature.

The four-point probe measurement was conducted to obtain the sheet resistivity of the counter electrodes. Each four-point probe measurement was performed on 3 blank FTO substrates and 2 counter electrode variations in order to compare the sheet resistivity for every sample. Five measurement data were retrieved for each sample to minimize the measurement errors. The results of the measurements obtained in this characterization can be seen in Table 2. The resistance value of the FTO sample is used as the reference parameter. The average sheet resistance of blank FTO was approximately 14.05 $\Omega /$ sq. If uncoated FTO substrate was used without catalyst layer, then there is a possibility that the FTO will not be able to pull all the trapped electrons and make the electrons move back toward the photoelectron layer.

Therefore, a layer that is capable of assisting the FTO layer in the electron transport process of a smaller resistance value is required.The smaller the resistance value of a material, the better the electrode conductivity and thus the electron transfer can be enhanced.

TABLE 1

COMPOSITIONS OF CARBON PASTE USED IN THIS STUDY

\begin{tabular}{|c|c|c|}
\hline \multirow{2}{*}{ Materials } & \multicolumn{2}{|c|}{ Carbon Paste } \\
\cline { 2 - 3 } & CNP & AC \\
\hline Activated Carbon $(\mathrm{g})$ & - & 0.5 \\
\hline Carbon nanopowder $(\mathrm{g})$ & 0.5 & - \\
\hline Graphite $(\mathrm{g})$ & 2 & 2 \\
\hline Ethyl-cellulose $(\mathrm{g})$ & 0.3 & 0.3 \\
\hline TiO $(\mathrm{P} 25)(\mathrm{g})$ & 0.25 & 0.25 \\
\hline Terpineol (ml) & 4.25 & 4.25 \\
\hline
\end{tabular}


TABLE 2

CHARACTERISTIC OF CARBON-BASED COUNTER ELECTRODE AND CARBON COMPOSITE PASTE IN THIS STUDY

\begin{tabular}{|c|c|c|}
\hline \multirow{2}{*}{ Characteristics } & \multicolumn{2}{|c|}{ Carbon Paste } \\
\hline & CNP & $\mathrm{AC}$ \\
\hline Average thickness $(\mu \mathrm{m})^{*}$ & $16.4 \pm 3.5$ & $10.4 \pm 4.1$ \\
\hline Average $\mathrm{R}$ sheet $(\Omega / \mathrm{sq})^{* *}$ & $11.09 \pm 0.7$ & $10.70 \pm 0.4$ \\
\hline BET surface area $\left(\mathrm{m}^{2} / \mathrm{g}\right)^{* * *}$ & 49.4 & 54.2 \\
\hline
\end{tabular}

Therefore, the I-V characteristics and solar cell efficiency can be improved [9]. Table 2 shows that the lowest sheet resistance value was obtained by the carbon paste that uses activated carbon compared to the resulting sheet resistance value of carbon paste using carbon nanopowder are $10.70 \Omega /$ sq and $11.09 \Omega /$ sq.

SEM characterization was carried out to analyze the morphology of the carbon surface on the monolithic DSSC. SEM characterizations were performed on monolithic DSSC solar cell samples with carbon paste variations under $20.000 \times$ magnification. The SEM images are displayed in Figure 2. Carbon nanopowder has a morphology which tends to be agglomerated and its form is not homogeneous and its distribution is uneven. Small size agglomerates tend to form small groups of grains while the large agglomerates had somewhat flat surfaces. Activated carbon has a morphology with sharply angled agglomerates and the form is not homogeneous. In comparison with the second SEM characterization of the carbon paste, activated carbon has a more porous morphology than carbon nanopowder. A porous surface structure is desirable on the counter electrode layer, since with a porous structure more electrons are captured from the outer circuit and allowing faster electrons to be received by the electrolyte. Thus the electron transfers process and the redox cycles on the electrolyte progressively faster [6]. Although both carbon pastes are in the form of agglomerates, activated carbon has fewer agglomerates and is evenly distributed compared to carbon nanopowder. This agglomerate decreases electrical contact because it causes a greater resistance and the electron transfer process becomes slower and affects the performance of the DSSC [6].

XRD analysis was performed to further characterize the structure and crystal phase of the carbon paste. Figure 3 shows the XRD spectrum of carbon paste containing activated carbon. Since both carbon nanopowder and activated carbon were amorphous, the XRD spectra of the carbon paste containing either type of carbon were exactly similar, thus only one XRD pattern was shown in Figure 3. It was confirmed that the crystalline peaks on the XRD spectrum were mainly originated from the crystallinity of graphite (JCPDS no. 025-0284) and $\mathrm{TiO}_{2} \mathrm{P} 25$ binder that were existed in anatase (JCPDS no. 021-172) and rutile (JCPDS no. 021-1276) phase.

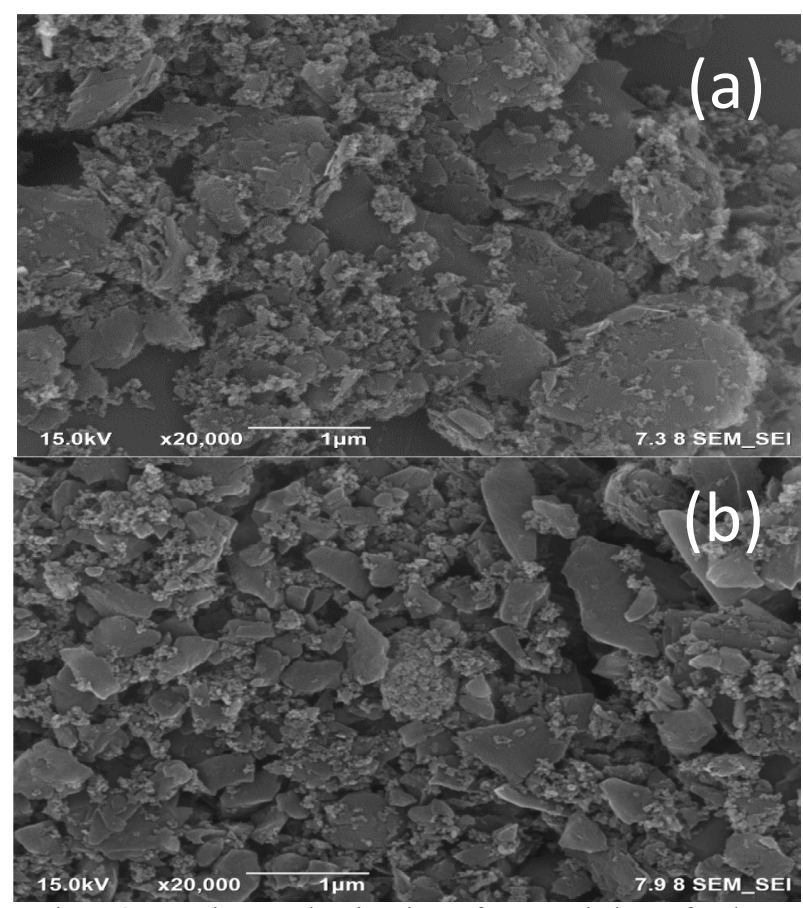

Figure 2. SEM images showing the surface morphology of carbon paste using (a) carbon nanopowder (b) activated carbon.

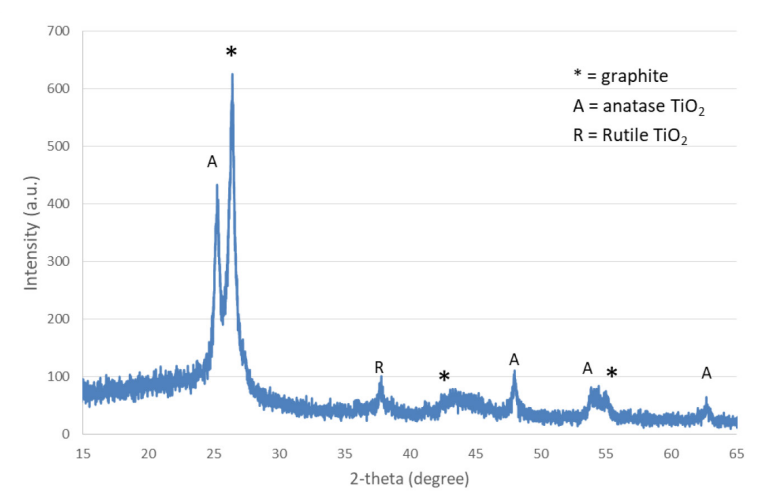

Figure 3. XRD pattern of carbon paste containing activated carbon.

Table 2 shows that the carbon paste using activated carbon has slightly larger BET surface area compared to carbon pastes using carbon nanopowder (i.e., $54.2 \mathrm{~m}^{2} / \mathrm{g}$ and $49.4 \mathrm{~m}^{2} / \mathrm{g}$, respectively). This result is in agreement with the BET surface area measurements of the activated carbon that is higher than the surface area of the carbon nanopowder $\left(1000 \mathrm{~m}^{2} / \mathrm{g}\right.$ and $310 \mathrm{~m}^{2} / \mathrm{g}$ for pure activated carbon and carbon nanopowder, respectively). Counter electrodes with high surface area increases the electron interaction with the electrolyte [10]. The higher the surface area, the more electrons are generated and the consequently the DSSC performance will be improved [10].

The performance of the monolithic DSSC solar cell can be known by measuring the characteristics of the I$\mathrm{V}$ curve. The characterization of solar cells was carried out by measuring the current-voltage (I-V). The active area of each sample was $0.25 \mathrm{~cm}^{2}$. The efficiency data obtained by varying the counter electrode yielded different results. The data is shown in Table 3, while the $\mathrm{I}-\mathrm{V}$ characteristic curves are shown in Figure 4.

Table 3 shows the results of I-V characterizations on monolithic DSSC with variations on the carbon paste. Carbon pastes that use activated carbon provided 
higher efficiency than carbon paste that uses carbon nanopowder. It can be seen from Table 3 that the monolithic DSSC with activated carbon-based counterelectrode exhibited better photovoltaic characteristics than the DSSC with carbon nanopowder counterelectrode. Despite having slightly lower FF, all of the electrical parameters such as $\mathrm{V}_{\mathrm{OC}}, \mathrm{I}_{\mathrm{SC}}, \mathrm{P}_{\max }$, and efficiency of the activated carbon containing DSSC were higher than those of DSSC with carbon nanopowder counter electrode. We suspected that the slightly lower FF value exhibited by the sample with activated carbon was rather caused by an external factor, in this case a poor contact between the FTO substrate and the terminals, rather than caused by the quality of the internal resistances (e.g. $R_{S}$ or $R_{S H}$ ). $\mathrm{V}_{\mathrm{OC}}$ values play a significant role in the process of charge injection in cells in the DSSC. Almost half the energy of photons lost in the cell due to dye regeneration [7]. In Table 3, the activated carbon has a higher $\mathrm{V}_{\mathrm{OC}}$ value compared to $\mathrm{V}_{\mathrm{OC}}$ carbon nanopowder. This trend suggests that the charge transfer between activated carbon and electrolyte occurred more effectively than that in the carbon nanopowder. It is also supported by the sheet resistance data that shows counter electrode with activated carbon had a lower resistance value compared to the resistance values of the counter electrode that uses carbon nanopowder. The lower the resistance value, the better the solar cell will perform because the cathode will be more conductive. The more carbon that can attach to the FTO substrate, the wider the contact area of the counters electrode with the electrolyte solution. Consequently, the I-V characterization and the resulting efficiency will be improved [11].

The photoconversion efficiencies of DSSC solar cells in this work are relatively lower compared to other works that reporting similar concept, i.e. monolithic DSSC featuring Pt-free counter electrodes. For example, Kay and Gratzel reported an efficiency of $5.3 \%$ [12] and Vesce et al. obtained a photoconversion efficiency as high as $\sim 5 \%$, both using carbon-based counter electrodes [9]. Although a direct comparison between this work and those in the literature is not necessarily appropriate due to the discrepancies during the I-V measurement setup (e.g. the sun intensity used), fabrication protocols or even the materials used (i.e. the type of dye, electrolyte, etc.), we suspected that there are several factors that could be accountable for the relatively low efficiency achieved in this work. One of the responsible factor is the thickness of the catalyst layer. In this case, the thickness of carbon pastes is too thin, which is approximately 9-21 $\mu \mathrm{m}$. The thickness of the counter electrode is preferably in the range of 60-70 $\mu \mathrm{m}$ to get low resistance, giving the optimized cell a photoconversion efficiency of $4.9 \%$ [9]. Thicker counter electrode layer can lead to lower series resistance, $R_{S}$, which in turn resulting in increased efficiency, $J_{S C}$, and $V_{O C}$ values [9], [13]. There are also several other minor factors, such as room temperature and humidity during cell fabrication, which could also influence the relatively low-performance value of DSSC cells.
TABLE 3

PHOTOVOLTAIC PARAMETERS OF MONOLITHIC DSSC WITH DIFFERENT COUNTER ELECTRODE MEASURED UNDER AM 1.5

\begin{tabular}{|c|c|c|}
\hline \multirow{2}{*}{ Parameters } & \multicolumn{2}{|c|}{ Carbon Paste } \\
\cline { 2 - 3 } & CNP & AC \\
\hline $\mathrm{I}_{\mathrm{SC}}(\mathrm{mA})$ & $2.06 \times 10^{-2}$ & $1.79 \times 10^{-1}$ \\
\hline $\mathrm{V}_{\mathrm{OC}}(\mathrm{V})$ & 0.10 & 0.63 \\
\hline $\mathrm{P}_{\max }(\mathrm{mW})$ & $6.86 \times 10^{-4}$ & $2.76 \times 10^{-2}$ \\
\hline $\mathrm{FF}$ & 0.33 & 0.24 \\
\hline $\mathrm{R}_{\mathrm{S}}(\Omega)$ & Not measured & $4.19 \times 10^{3}$ \\
\hline $\mathrm{R}_{\mathrm{SH}}(\Omega)$ & Not measured & $3.05 \times 10^{3}$ \\
\hline$\eta(\%)$ & 0.005 & 0.221 \\
\hline \multicolumn{2}{|c|}{$(\%)$} & Note: The value cannot be measured as it was outside of the measurable range.
\end{tabular}

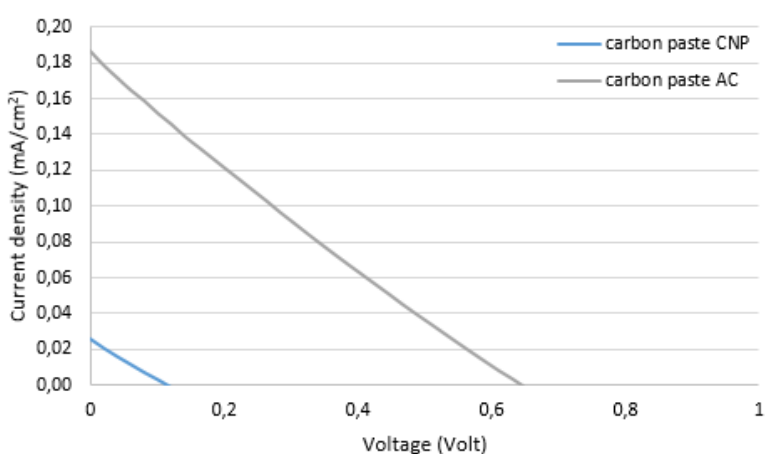

Figure 4. I-V characteristics of monolithic DSSC using various carbon counter electrodes.

In addition to being affected by layer resistance and thickness, DSSC performance could also be affected by surface area and surface morphology of the counter electrode. The surface area of the counter electrode plays an important role in increasing the DSSC performance. The higher the surface area of the counter electrode, the better the resulting DSSC performance. The high surface area causes the electron transfer process faster. The higher the surface area, the faster the electron transfer process and the faster the DSSC produces electricity [14]. In this work, the surface area of the resulting carbon pastes is lower than the surface area of pure carbon nanopowder and activated carbon. Therefore, the paste compositions and/or the synthesis method will need to be optimized to produce a higher surface area. Agglomerated carbon pastes could reduce electrical contacts and lead to higher resistance and, consequently slowing down the electron transfer process [6].

\section{CONCLUSION}

Monolithic DSSC has been fabricated on a single FTO substrate using carbon paste as a counter electrode. The type of carbon material was varied to determine the effect on monolithic DSSC performance. Four-point probe measurement revealed that the carbon paste exhibited slightly higher conductivity with a sheet resistance of $10.70 \Omega / \mathrm{sq}$ and $11.09 \Omega / \mathrm{sq}$, for activated 
carbon and carbon nanopowder, respectively. The efficiency of DSSC using activated carbon as counter electrode produced a higher percentage than carbon nanopowder, which is $0.221 \%$ and $0.005 \%$ for activated carbon and carbon nanopowder, respectively. The use of activated carbon as a counter electrode gave better results than carbon nanopowder because the conductivity of the activated carbon is higher as shown by the four-point probe measurements and it also has relatively higher surface area.

\section{ACKNOWLEDGEMENT}

We would like to thank the member of Materials and Devices for Solar Cell research group at the Research Center for Electronics and Telecommunication, Indonesian Institute of Sciences (P2ET-LIPI). Research Center of Physics LIPI (P2FLIPI) is acknowledged for performing the SEM, XRD and gas sorption measurements. This research was funded by INSINAS Research Program 2017-2018 by Ministry of Research, Technology and Higher Education of The Republic of Indonesia entitled "Design, Fabrication and Up-scaling of Monolithic Dye-sensitized Solar Modules for Indoor Applications."

\section{REFERENCES}

[1] S. Yuliananda, G. Sarya., and RA. R Hastijanti, "Pengaruh perubahan intensitas matahari terhadap daya keluaran panel surya," Jurnal Pengabdian LPPM Untag Surabaya, vol. 01, pp. 193-202, Nov. 2015.

[2] S. Sidopekso, " Uji karakteristik sel surya pada sistem 24 volt DC sebagai catudaya pada sistem pembangkit tenaga hybrid," in Proc. Pertemuan Ilmiah XXVI HFI Jateng \& DIY, Purworejo, 2012, pp. 208-212.

[3] R. Prasetyowati, "Sel surya berbasis titania sebagai sumber energi listrik alternatif," in Proc. Seminar Nasional Penelitian, Pendidikan dan Penerapan MIPA, 2012, pp. 1-6.
[4] L. Muliani, E. S. Rosa, J. Hidayat, Shobih, and B. Yuliarto," Pembuatan sel surya berbasis dye-sensitized menggunakan substrat fleksibel," in Proc. InSINas, 2012, p. 22-26.

[5] M. S. W. Kumara, G. Prajitno, 2012, "Studi awal fabrikasi dye sensitized solar cell (DSSC) dengan menggunakan ekstraksi daun bayam (Amaranthus Hybridus L.) sebagai dye sensitizer dengan variasi jarak sumber cahaya pada DSSC," Jurnal Ilmiah ITS, 2012.

[6] N. Puspitasari, et al., "Pengaruh jenis katalis pada elektroda pembanding terhadap efisiensi dye sensitized solar cells dengan klorofil sebagai dye sensitizer," in Jurnal Fisika dan Aplikasinya, vol. 13, no.1, pp. 30-33, Jan. 2017.

[7] N. M. Nursam, A. Istiqomah, J. Hidayat, P. N. Anggraini, Shobih "Analysis of Catalytic Material Effect on the Photovoltaic Properties of Monolithic Dye-sensitized Solar Cells," Jurnal Elektronika dan Telekomunikasi, vol. 17, no. 2, pp. 30-35, Dec. 2017.

[8] A. Y. Dewi, "Pemanfaatan energi surya sebagai suplai cadangan pada laboratorium elektro dasar di Institut Teknologi Padang," Jurnal Teknik Elektro ITP, vol. 2, no. 3, pp. 20-28, Nov. 2013.

[9] L. Vesce, et al., "Fabrication of Spacer and Catalytic Layers in Monolithic Dye-Sensitized Solar Cells," IEEE J. Photovoltaics, vol. 3, no. 3, pp. 1004-1011, Jul. 2013.

[10] Y. Rong, H. Han, "Monolithic quasi-solid-state dye-sensitized solar cells based on graphene-modified mesoscopic carboncounter electrodes," J. Nanophotonics, vol.7, no. 1, pp. 1-10, Jun. 2013.

[11] S. Ito, K. Takahashi, "Fabrication of monolithic dye- sensitized solar cell using ionic liquid electrolyte," Int. J. Photoenergy, vol. 2012, Feb. 2012

[12] A. Kay, M. Gratzel, "Low cost photovoltaic modules based on dye sensitized nanocrystalline titanium dioxide and carbon powder," Solar Energy Materials and Solar Cells, vol. 44, no.1, pp. 99-117, Oct. 1996.

[13] C. Y. Chen, et al., "Highly efficient light-harvesting ruthenium sensitizer for thin-film dye-sensitized solar cells," ACS Nano, vol.3, no. 10, pp. 3103-3109, Sep. 2009.

[14] R. S. Bawono, "Analisis perbandingan performa sel surya tersensitasi zat pewarna terbuat dari lapisan $\mathrm{TiO}_{2}$ hasil sintesis pasca-hidrotermal dengan $\mathrm{TiO}_{2}$ P-25 degussa," B. Eng. Thesis, Materials and Energy Engineering Study Program, University of Indonesia, Depok, Indonesia, Dec. 2014. 